\title{
A Filosofia da Liberdade na Saga de Filmes Star Wars - Parte $1^{*}$
}

\author{
Alex Catharino**
}

\begin{abstract}
Resumo: $\mathrm{O}$ artigo analisa as noções de liberdade e de escolha humanas que permeiam a saga de filmes Guerra nas Estrelas, do cineasta George Lucas. Além de abordar a narratologia da série a partir das teorias do monomito de Joseph Campbell, o autor demonstra que as histórias também podem ser compreendidas à luz da noção de imaginação moral de Russell Kirk. O autor discute os aspectos filosóficos e praxeológicos da estória e ressalta como estas narrativas podem ser apropriadas como exemplos ilustrativos de algumas propostas teóricas da Escola Austríaca de Economia.
\end{abstract}

Palavras-Chave: Crítica Cinematográfica, Filosofia da Cultura, Ética, Liberdade, Guerra nas Estrelas.

\section{The Philosophy of Liberty in the Star Wars Movies - Part 1}

\begin{abstract}
The article analyzes notions as individual liberty and human choices which permeate Star Wars movies saga, created by the moviemaker George Lucas. Besides addressing the series narratology from the monomyth theories of Joseph Campbell, the author shows that these stories also can be seen in the light of Russell Kirk's notion of Moral Imagination. The author discusses the story philosophical and praxeological aspects and emphasizes how these narratives may be appropriated as illustrative examples of some theoretical proposals of Austrian School of Economics.
\end{abstract}

Keywords: Film Criticism, Philosophy of Culture, Ethics, Liberty, Star Wars.

Classificação JEL: B53, Z1

\begin{abstract}
* O presente ensaio é a primeira parte da versão revisada e ampliada do texto da palestra de mesmo título apresentada, em 7 de setembro de 2013, como parte da programação da II Conferência Nacional dos Estudantes Pela Liberdade (EPL), realizada, entre 7 e 8 de setembro de 2013, em Belo Horizonte, MG. A segunda e última parte do ensaio será publicada na próxima edição (Volume II, Número 2) de MISES: Revista Interdisciplinar de Filosofia, Direito e Economia.
\end{abstract}

** Alex Catharino é vice-presidente executivo do Centro Interdisciplinar de Ética e Economia Personalista (CIEEP), gerente editorial dos periódicos COMMUNIO: Revista Internacional de Teologia e Cultura e MISES: Revista Interdisciplinar de Filosofia, Direito e Economia, e pesquisador residente do Russell Kirk Center for Cultural Renewal, em Mecosta, Michigan, nos EUA. Cursou a graduação em História na Universidade Federal do Rio de Janeiro (UFRJ) e fez estudos nas áreas de História, Arqueologia, Paleografia, Filosofia, Teologia, Literatura, Economia e Ciência Política em diferentes instituições no Brasil, EUA, Portugal, Itália, Argentina, Colômbia e Uruguai. Foi visiting fellow da Atlas Economic Research Foundation, em Washington, D.C., nos EUA. É autor de inúmeros artigos publicados em diferentes periódicos acadêmicos, bem como do capítulo "Origens e Desenvolvimento do Liberalismo Clássico" no livro Ensaios sobre Liberdade e Prosperidade (UNA Editoria, 2001), dos verbetes "Eric Voegelin (1901-1985)", "Liberalismo" e "Russell Kirk (1918-1994)" no Dicionário de Filosofia Política (Editora UNISINOS, 2010), dos estudos introdutórios "A Vida e a Imaginação de Russell Kirk" e "A Formação e o Desenvolvimento do Pensamento Conservador de Russell Kirk" para as edições brasileiras dos livros A Era de T. S. Eliot: A Imaginação Moral do Século XX (É Realizações, 2011) e A Política da Prudência (É Realizações, 2013) de Russell Kirk, e dos posfácios “Teologia e História na Reconstrução da Unidade Cristã" e "Em Busca da Cristandade Perdida" para as edições brasileiras dos livros A Formação da Cristandade (É Realizações, 2014) e A Divisão da Cristandade (É Realizações, 2014) de Christopher Dawson.

E-mail: alex@mises.org.br 
As produções cinematográficas da década de 1970, em grande parte, eram marcadas por uma atmosfera sombria ou distópica que refletiam o contexto cultural marcado pelo pessimismo decorrente dos eventos históricos da Guerra do Vietnã, da Crise Mundial do Petróleo e do Caso Watergate. Diante desse desolador ambiente cultural, político e econômico, o cineasta norte-americano George Lucas se propôs, de forma consciente, a criar uma aventura que passasse valores positivos para a juventude, recuperando certa ingenuidade perdida e reacendendo a chama da esperança nas gerações emergentes. Sua ideia era revalorizar a imagem do herói, em oposição aos modelos de anti-heróis ou justiceiros dos filmes do período, fazendo uma estória com o otimismo das "aventuras de capa e espada" que animaram sua infância e juventude, durante as décadas de 1940 e 1950, nas matinês de sábado.

O resultado dessa empreitada artística e comercial de George Lucas é a franquia Star Wars, ou Guerra nas Estrelas. A saga Star Wars foi popularizada, principalmente, por duas trilogias de filmes. A trilogia mais antiga é composta pelos episódios IV, V e VI da série, que são respectivamente os seguintes filmes: Guerra nas Estrelas, lançado originalmente em 25 de maio de 1977 e denominado, posteriormente, por George Lucas como Uma Nova Esperança; O Império Contra-Ataca, lançado em 21 de maio de 1980; e O Retorno de Jedi, lançado em 25 de maio de $1983^{1}$. A trilogia mais recente

\footnotetext{
${ }^{1}$ Dentre outras edições, os filmes dessa trilogia estão disponíveis, em DVDs simples, na seguinte edição:

Star Wars: Episódio IV - Uma Nova Esperança. Direção: George Lucas. Produção: Gary Kurtz. Roteiro: George Lucas. Intérpretes: Mark Hamill, Harrison Ford, Carrie Fisher, Peter Cushing, Alec Guinness e outros. Manaus: Twentieth Century Fox Home Entertainment Brasil, 2004. DVD (121 minutos).

Star Wars: Episódio $V$ - O Império Contra-Ataca. Direção: Irvin Kershner. Produção: Gary Kurtz. Roteiro: Leigh Brackett e Lawrence Kasdan, baseado numa estória de George Lucas. Intérpretes: Mark Hamill, Harrison Ford, Carrie
}

é formada pelos episódios I, II e III da série, a saber: A Ameaça Fantasma, lançado em 19 de maio de 1999; Ataque dos Clones, lançado em 16 de maio de 2002; e A Vingança dos Sith, lançado em 19 de maio de $2005^{2}$.

A ideia original de George Lucas era produzir apenas uma película, no entanto, ao escrever o roteiro do filme, o cineasta norte-americano viu que a estória ficou muito maior do que esperava e, como numa ópera, resolveu

Fisher, Billy Dee Williams, Alec Guinness e outros. Manaus: Twentieth Century Fox Home Entertainment Brasil, 2004. DVD (124 minutos).

Star Wars: Episódio VI - O Retorno de Jedi. Direção: Richard Marquand. Produção: Howard G. Kazanjian. Roteiro: George Lucas e Lawrence Kasdan, baseado numa estória de George Lucas. Intérpretes: Mark Hamill, Harrison Ford, Carrie Fisher, Billy Dee Williams, Alec Guinness e outros. Manaus: Twentieth Century Fox Home Entertainment Brasil, 2004. DVD (131 minutos).

Esses DVDs foram lançados numa caixa com um quarto disco de extras, que inclui o documentário Empire of Dreams: The History of The Star Wars Trilogy [O Império dos Sonhos: A História da Trilogia Star Wars], dirigido por Edith Becker e Kevin Burns. Todas as referências aos filmes no presente artigo terão como base essa edição.

${ }^{2}$ As referências aos filmes no presente artigo são feitas a partir das versões em DVDs duplos, com extras, nas seguintes edições:

StaR WARs: Episódio I - A AmEAÇA FANTASMA. Direção: George Lucas. Produção: Rick McCallum. Roteiro: George Lucas. Intérpretes: Liam Neeson, Ewan McGregor, Natalie Portman, Jake Lloyd, Ian McDiarmit e outros. Manaus: Twentieth Century Fox Home Entertainment Brasil, 2000. DVD (131 minutos).

StAR WARs: EPISÓDio II - ATAQUe dos clones. Direção: George Lucas. Produção: Rick McCallum. Roteiro: Jonathan Hales e George Lucas. Intérpretes: Ewan McGregor, Natalie Portman, Hayden Christensen, Ian McDiarmit, Samuel L. Jackson, Christopher Lee e outros. Manaus: Twentieth Century Fox Home Entertainment Brasil, 2002. DVD (144 minutos).

Star Wars: Episódio III - A Vingança dos Sith. Direção: George Lucas. Produção: Rick McCallum. Roteiro: George Lucas. Intérpretes: Ewan McGregor, Natalie Portman, Hayden Christensen, Ian McDiarmit, Samuel L. Jackson, Christopher Lee e outros. Manaus: Twentieth Century Fox Home Entertainment Brasil, 2005. DVD (146 minutos). 
dividi-la em três partes, que viriam a constituir, respectivamente, os episódios IV, V e VI da série. $O$ cineasta também elaborou um guia sobre cada uma das personagens, criando a história de fundo sobre vida de cada uma delas, o que acabou servindo de base para a criação, posteriormente, dos episódios I, II e III ${ }^{3}$.

Seja por intermédio dos seis filmes criados por George Lucas, pelos 25 desenhos animados Clone Wars [Guerra dos Clones] de Genndy Tartakovsky, pelo filme em 3D e pelos 121 episódios, em seis temporadas, do seriado de televisão Star Wars: The Clone Wars [Guerra nas Estrelas: Guerra dos Clones] de Dave Filoni, pelas estórias veiculadas nos livros e nos quadrinhos que compõem o chamado universo expandido ou pelos inúmeros produtos comercializados com a marca da franquia, bem como por algumas paródias ou referências em outras obras da cultura pop, a "mitologia" de Star Wars e suas personagens já fazem parte do imaginário contemporâneo da civilização ocidental.

A saga é, também, uma das empreitadas culturais mais bem sucedidas do ponto de vista comercial, pois apenas os seis filmes da série já renderam quase cinco bilhões de dólares. A compra por mais de quatro bilhões de dólares da empresa Lucasfilm e dos direitos sobre a franquia Star Wars, em 2012, pela The Walt Disney Company foi acompanhada do anúncio de que serão produzidos os episódios VII, VIII e IX da série, constituindo uma nova trilogia, cujo lançamento da primeira película está programado para o dia 18 de dezembro de 2015. Acreditamos que esses lançamentos irão ampliar, ainda mais, a influência cultural de Star Wars.

Em outro artigo acadêmico já tivemos a oportunidade de analisar os pontos centrais e os fundamentos da narratologia de Star Wars, enfatizando como a saga é um importante

\footnotetext{
${ }^{3}$ A história da criação da série Star Wars se encontra no já citado documentário Empire of Dreams. A intencionalidade do projeto moralizante de George Lucas é narrada pelo próprio autor nesse documentário, bem como nos comentários de áudio nas edições em DVD dos seis filmes da série.
}

meio para a formação da Imaginação Moral, tal como definida por Russell Kirk (1918-1994), e o modo como a série pode ser utilizada para reforçar importantes concepções teológicas e filosóficas cristãs, além apresentar uma breve digressão sobre a teoria política contida em Star Wars, enfatizando a ideia de que os problemas do ordenamento social encontram suas raízes nas desordens interiores da alma dos indivíduos ${ }^{4}$. No presente ensaio, diferente de nosso trabalho anterior sobre a temática, não nos deteremos tanto nas possíveis apropriações religiosas como instrumento apologético; nosso objetivo principal aqui é aprofundar a análise de alguns aspectos políticos veiculados pela narrativa, sem negligenciar o caráter eminentemente moralizante que sustenta a estória.

Defendemos que o impacto cultural e os valores morais veiculados pelos filmes da saga Star Wars devem ser apropriados como um importante material didático pelos defensores da liberdade. Nas palavras de Ludwig von Mises (1881-1973):

Tudo o que ocorre na sociedade de nossos dias é fruto de ideias, sejam elas boas, sejam elas más. Faz-se necessário combater as más ideias. Devemos lutar contra tudo o que não é bom na vida pública. Devemos substituir as ideias errôneas por outras melhores, devemos refutar as doutrinas que promovem a violência sindical. É nosso dever lutar contra o confisco da propriedade, o controle de preços, a inflação e contra tantos outros males que nos assolam. Ideias, e somente ideias, podem iluminar a escuridão. As boas ideias devem ser levadas às pessoas de tal modo que elas se convençam de que essas ideias são as corretas, e saibam quais são as errôneas ${ }^{5}$.

De acordo com os renomados libertários norte-americanos Jeffrey Tucker e Lew

${ }^{4}$ CATHARINO, Alex. A Imaginação Moral em Star Wars. COMMUNIO: Revista Internacional de Teologia e Cultura, Vol. XVIII, No. 1 (Ed. 101 / Jan.Mar. 2009): 221-52.

${ }^{5}$ MISES, Ludwig von. As Seis Lições. Trad. Maria Luiza Borges. São Paulo: Instituto Ludwig von Mises Brasil, 7ª Ed., 2009. p. 101. 
Rockwell, a intransigente defesa da liberdade feita por Ludwig von Mises "adotou muitas das perspectivas culturais que fundamentam o conservadorismo tradicionalista em voga nos Estados Unidos moderno". . Assentimos com essa perspectiva por acreditarmos que, diferente do que apregoam as vãs polêmicas nas redes sociais, existem diversos pontos de interseção entre os libertários de linhagem austríaca e os conservadores de tradição burkeana, que necessitam ser explorados de modo mais efetivo na propagação de boas ideias que colaborem com a defesa da ordem, da liberdade e da justiça contra as más ideias que propõem o avanço da esfera estatal em detrimento da autonomia individual ou das tradições morais, tal como advogado de modo distinto pelas diferentes ideologias progressistas ou reacionárias que marcaram o panorama intelectual do ocidente nos últimos três séculos ${ }^{7}$. Ao mesmo tempo em que rejeitamos a proposta simplista do "fusionismo", por reconhecermos a existência de certas distinções teóricas irreconciliáveis entre o libertarianismo e conservadorismo, que fazem da identidade de cada uma dessas vertentes ${ }^{8}$, também, acreditamos na possibilidade de diálogo sobre alguns pontos de interseção das propostas dos libertários de linhagem austríaca e dos princípios advogados

${ }^{6}$ TUCKER, Jeffrey A. \& ROCKWELL JR., Llewellyn H. O Pensamento Cultural de Ludwig von Mises. Trad. Davi J. Dias. MISES: Revista Interdisciplinar de Filosofia, Direito e Economia, Vol. I, No. 1 (Jan.-Jun. 2013): 191-213. Cit. p. 210.

${ }^{7}$ A temática foi abordada com maior profundidade em: CATHARINO, Alex. A Escola Austríaca entre a Tradição e a Inovação. MISES: Revista Interdisciplinar de Filosofia, Direito e Economia, Vol. I, No. 2 (Jul.Dez. 2013): 305-323.

8 A principal crítica libertária ao "fusionismo" advogado por Frank S. Meyer (1909-1972) aparece em: ROTHBARD, Murray N. Frank S. Meyer: The Fusionist as Libertarian Manqué. Modern Age, Volume 25, Number 4 (Fall 1981): 352-63. Para uma crítica do ponto de vista conservador, ver: KIRK, Russell. Uma Avaliação Imparcial dos Libertários. In: A Política da Prudência. Apres. Alex Catharino; Intr. Mark C. Henrie; Trad. Gustavo Santos e Márcia Xavier de Brito. São Paulo: É Realizações, 2013. p. 227-40. pelos conservadores de tradição burkeana. Vale ressaltar, que o eminente pensador libertário Hans Hermann-Hoppe justificou alguns motivos pelos quais "os conservadores da atualidade devem ser libertários antiestatistas", além apresentar as razões pelas quais "os libertários devem ser conservadores" $"$. Como ressaltou o F. A. Hayek (1899-1992):

O importante, agora, é que teremos de encontrar um consenso em torno de certos princípios e de nos libertar de alguns erros que pautaram a nossa conduta nas últimas décadas [...] Agora, é mais importante remover os obstáculos com que a insensatez humana obstruiu o nosso caminho e liberar a energia criadora dos indivíduos, do que inventar novos mecanismos para "guiá-los" e "dirigi-los" - criar condições favoráveis ao progresso, em vez de "planejar o progresso". A primeira necessidade é libertarmo-nos da pior forma de obscurantismo contemporâneo: aquela que procura

persuadir-nos de que nossa conduta no passado recente foi, ou acertada, ou inevitável. Não nos tornaremos mais sábios enquanto não aprendermos que muito do que fizemos era pura tolice ${ }^{10}$.

Na atuação em defesa de uma ordem social que proteja a liberdade dos indivíduos e promova a justiça, tanto os conservadores quanto os libertários deverão utilizar com mais frequência os apelos à "imaginação moral", evitando restringir a defesa de seus princípios exclusivamente por intermédio de argumentos racionais. Não convenceremos a maioria das pessoas, incluindo uma parcela significativa dos formadores da opinião pública, apenas com argumentos lógicos que demonstrem a superioridade de nossas propostas, é neces-

${ }^{9}$ HOPPE, Hans-Hermann. Democracia, o deus que falhou: A Economia e a Política da Monarquia, da Democracia e da Ordem Natural. Trad. Marcelo Werlang de Assis São Paulo: Instituto Ludwig von Mises Brasil, 2014. p. 225.

${ }^{10}$ HAYEK, F. A. O Caminho da Servidão. Trad. Anna Maria Capovilla, José Ítalo Stelle e Liane de Morais Ribeiro. São Paulo: Instituto Ludwig von Mises Brasil, 6 ${ }^{\mathrm{a}}$ Ed., 2010. p. 221. 
sário sustentarmos que a defesa da liberdade individual e todas as propostas decorrentes deste é um imperativo moral. Mais do que convencer, precisamos encantar.

A experiência histórica do século $X X$ demonstrou que independente dos defensores da liberdade possuírem as melhores teorias e as evidencias empíricas em seu favor, as ideologias reacionárias ou progressistas avançaram nos campos político e econômico com amplo apoio das massas, pois, como alertou Russell Kirk, "a convicção não é produzida pela lógica da linguagem, nem pela acumulação dos fatos"11. Desse modo, não basta termos as melhores ideias acerca da natureza humana ou do ordenamento político e econômico da sociedade, se não possuirmos os meios adequados para propagar tais noções, pois existem inúmeras relações entre o conceito de imaginação moral, tal como apresentado pelo conservadorismo kirkeano, e a defesa da "liberdade moral" ou "liberdade interior", tal como definida pela terminologia hayekiana ${ }^{12}$. Nesse sentido:

As estórias permeadas pela imaginação moral apresentam suas personagens como criaturas dotadas de livre-arbítrio, logo a escolha entre o bem e o mal é a decorrência de ações voluntárias. A opção entre fazer o que é certo, mesmo contrariando a própria vontade e se sacrificando, ou seguir o caminho mais fácil, tentando manipular a realidade, é o que diferencia uma personagem boa de uma má. Assim como em $O$ Senhor dos Anéis, em As Crônicas de Nárnia ou em Harry Potter, em Star Wars verificamos que as personagens não são vitimas das armadilhas do destino, mas são livres para escolher entre fazer o bem ou o mal ${ }^{13}$.

${ }^{11}$ KIRK, Russell. The Conservative Mind: From Burke to Eliot. Pref. Henry Regnery. Washington, D.C.: Regnery Publishing, 7ª ed. rev., 1986. p. 284.

${ }^{12}$ HAYEK, F. A. Os Fundamentos da Liberdade. Intr. Henry Maksoud; Trad. Anna Maria Capovilla e José Ítalo Stelle. Brasília / São Paulo: Editora Universidade de Brasília / Visão, 1983. p. 9-10.

${ }^{13}$ CATHARINO. A Imaginação Moral em Star Wars. p. 242.
Antes de continuarmos nossa explicação sobre o conceito kirkeano de imaginação moral, acreditamos ser necessário apresentarmos as definições de liberdade adotadas pela Escola Austríca. De acordo com Ludwig von Mises:

O conceito de liberdade só faz sentido na medida em que se refere às relações inter-humanas. Existiram autores que nos falaram de uma liberdade original - natural - de que o homem teria desfrutado num mítico estado natural anterior ao estabelecimento das relações sociais. Entretanto, esses indivíduos ou famílias econômica e mentalmente autossuficientes, vagando pelo mundo, só eram livres na medida em que não encontravam pela frente alguém mais forte. $\mathrm{Na}$ impiedosa competição biológica, o mais forte tinha sempre razão e o mais fraco não tinha outra escolha a não ser a submissão incondicional. O homem primitivo certamente não nasceu livre.

Somente no contexto de um sistema social é que se pode atribuir um significado à palavra liberdade. No sentido praxeológico, o termo liberdade refere-se à situação na qual um indivíduo tem a possibilidade de escolher entre modos de ação alternativos. Um homem é livre na medida em que lhe seja permitido escolher os seus fins e os meios a empregar para atingi-los. A liberdade de um homem é rigidamente restringida pelas leis da natureza, bem como pelas leis da praxeologia. Ele não pode pretender atingir fins incompatíveis entre si. Há prazeres que provocam efeitos determinados no funcionamento do corpo e da mente; se quiser desfrutá-los, terá de sofrer as consequências. Seria absurdo dizer que o homem não é livre porque não pode, digamos drogar-se, sem sofrer as inevitáveis consequências consideradas como altamente indesejáveis. Embora isso seja evidente para todas as pessoas de bom senso, esta evidência não é bem percebida em situações análogas sujeitas às leis da praxeologia.

O homem não pode, ao mesmo tempo, pretender ter as vantagens decorrentes da cooperação pacífica em sociedade, sob a égide da divisão do trabalho, e permitir-se uma conduta que inevitavelmente terminará por desintegrar a sociedade. Tem 
necessariamente de escolher entre o respeito a certas regras que tornam a vida em sociedade possível ou a pobreza e a insegurança, se preferir "viver perigosamente", num estado de guerra constante entre indivíduos independentes. Esta é uma lei tão exata na determinação do resultado da ação humana como um todo quanto são as leis da física ${ }^{14}$.

A principal concepção de liberdade defendida pelos autores da Escola Austríaca é a de Liberdade Individual ou Liberdade Pessoal, entendida por F. A. Hayek como "o estado no qual o homem não está sujeito a coerção pela vontade arbitrária de outrem"15, e definida por Murray N. Rothbard (1926-1995) como "ausência de invasão, de qualquer propriedade ou pessoa, exercida por outro homem"16. Nesse sentido, há uma relação necessária entre a liberdade individual e a livre inciativa na esfera econômica, pois, tal como explica Mises:

O grau de liberdade que os indivíduos podem usufruir num contexto de cooperação social depende da harmonização do ganho privado com o bem público. $\mathrm{Na}$ medida em que o indivíduo, ao perseguir o seu próprio bem-estar, aumenta também - ou pelo menos não prejudica - o bem-estar de seus semelhantes, as pessoas podem dedicar-se às suas atividades como bem entenderem, sem que isso coloque em risco a preservação da sociedade e os interesses alheios. Surge, assim, um reino de liberdade e de iniciativa individual, um reino no qual o homem é livre para escolher e para agir como bem entender. É a existência dessa liberdade - que os socialistas e intervencionistas desdenhosamente intitulam de "liberdade econômica" - que torna possível a existência de todas as demais liberdades compatíveis com a cooperação social sob o signo da divisão

\footnotetext{
${ }^{14}$ MISES, Ludwig von. Ação Humana: Um Tratado de Economia. Trad. Donald Stewart Jr. São Paulo: Instituto Ludwig von Mises Brasil, 3를. Ed., 2010. p. 339.

${ }^{15}$ HAYEK. Os Fundamentos da Liberdade. p. 4.

${ }^{16}$ ROTHBARD, Murray N. A Ética da Liberdade. Intr. Hans-Hermann Hoppe; Trad. Fernando Fiori Chiocca. São Paulo: Instituto Ludwig von Mises Brasil, 2ª Ed., 2010. p. 101.
}

do trabalho. É a economia de mercado ou capitalismo, com seu corolário político (os marxistas diriam: com sua "superestrutura"), o governo representativo ${ }^{17}$.

Em termos filosóficos, a perspectiva adotada pela Escola Austríaca é a de Liberdade Negativa ("liberdade de"), no sentido de indicar a ausência de interferência dentro da esfera de ação da pessoa, em contraposição à chamada Liberdade Positiva ("liberdade para"), entendida como o domínio efetivo sobre si próprio e sobre o meio externo ${ }^{18}$. De acordo com Hayek, o conceito de liberdade individual não deve confundido com outros três significados distintos de liberdade, a saber:

1) A Liberdade Política, manifesta na "participação dos homens na escolha de seu governo, no processo legislativo e no controle da administração", sendo uma espécie de liberdade coletiva, compatível, em alguns casos, com a liberdade individual, que, no entanto, pode, em determinados contextos, entrar em conflito com a liberdade pessoal ao permitir a implantação da servidão individual aos poderes governamentais por intermédio do sistema democrático, visto que "um povo livre, nesse sentido, não é necessariamente um povo de homens livres, e não é preciso que o indivíduo compartilhe dessa liberdade coletiva para ser livre"19;

$\left.2^{\circ}\right)$ A Liberdade Interior ou Liberdade Moral, enquanto Livre Arbítrio ou "possibilidade de uma pessoa pautar-se em suas ações por sua própria vontade e consciência, por sua razão ou firme convicção e não por circunstâncias ou impulsos momentâneos", havendo inúmeros

\footnotetext{
${ }^{17}$ MISES. Ação Humana. p. 829.
}

${ }^{18} \mathrm{O}$ tema é debatido de forma mais sistemática, de um ponto de vista filosófico, por Sir Isaiah Berlin (19091997) na seguinte obra: BERLIN, Isaiah. Quatro Ensaios sobre a Liberdade. Trad. Wamberto Hudson Ferreira. Brasília: Editora Universidade de Brasília, 1981. No contexto da Escola Austríca o conceito de "liberdade negativa" é discutido de maneira mais ampla, em: HAYEK. Os Fundamentos da Liberdade. p. 3-18. Uma crítica aos modos como o conceito é utilizado tanto por Berlin quanto por Hayek é apresentada no seguinte texto: ROTHBARD. A Ética da Liberdade. p. 291-306.

${ }^{19}$ HAYEK. Os Fundamentos da Liberdade. p. 7-9. 
pontos comuns entre esse conceito e a noção de liberdade individual, sendo necessária uma diferenciação entre ambos apenas porque "a possibilidade de uma pessoa ser ou não capaz de uma escolha inteligente entre alternativas, ou de agir em conformidade com a resolução por ela tomada, é distinta da possibilidade de outras pessoas the imporem ou não seus desejos" ${ }^{\prime 20}$;

$3^{\circ}$ ) A Liberdade enquanto Poder, no sentido de possibilidade física para se fazer tudo o que quiser ou como capacidade se realizar todos os desejos, o que, além de uma ilusão, é incompatível tanto com a concepção de liberdade moral quanto com as concepções praxeológicas de liberdade. Tal concepção errônea conflita com as restrições físicas, morais e praxeológias da liberdade humana, fundamentando a ação livre não na ideia "negativa" de ausência de "coerção" injustificada, mas na concepção positiva de inexistência de qualquer forma de "restriçãa". De acordo com esse entendimento, é criada uma ideologia na qual "liberdade é poder, poder efetivo de fazer coisas específicas", difundido a perigosa noção progressista de que "exigir liberdade é exigir poder"21.

As narrativas ficcionais permeadas pela imaginação moral tendem a enfatizar a importância da 'liberdade interior' e, ao mesmo tempo, rejeitar a noção de 'liberdade enquanto poder'. Nesse sentido, não há nenhuma incompatibilidade entre a adoção da perspectiva cultural e ética conservadoras inerentes ao conceito de imaginação moral e a defesa da liberdade individual, tal como proposta pela Escola Austríaca.

A imaginação moral pode ser entendida como parte de um processo pessoal de descoberta da direção e do propósito da vida, "ao criar metáforas das experiências recordadas e ao empregar tais metáforas para sugerir úteis correlações com a experiência presente", transcendendo, assim, "a necessidade natural", pois, não é um mero instinto, sendo, ao mesmo tempo,

\footnotetext{
${ }^{20}$ Ibidem. p. 9-10.

${ }^{21}$ Ibidem. p. 10-12.
}

"atributo e expressão de liberdade, paixão e razão"22. As normas apresentadas pela imaginação moral são "inferidas dos séculos de experiência humana", sendo "novamente expressas de uma era para a outra"23. A noção de imaginação moral é um dos meios que possibilitam "discernir o que a pessoa humana pode ser, apreendendo, por alegorias, a correta ordem da alma e a justa ordem da sociedade" ${ }^{\prime 24}$.

A imaginação moral se opõe às duas formas corrompidas de imaginação. A primeira é a "imaginação idílica", um tipo anárquico que, na busca pela emancipação dos constrangimentos convencionais, se torna fantástica, isenta de restrições, primitivista, naturalista e utópica, numa total rejeição e revolta contra velhos dogmas, constrangimentos morais convencionais e costumes tradicionais. Tal forma corrompida de imaginário promove as noções revolucionárias, que nutrem falsas esperanças com a promessa de criação do paraíso terreno, necessariamente, fadada ao fracasso, por conta das próprias limitações da imperfectibilidade inerente à natureza humana. A segunda forma de imaginação corrompida é ideia de "imaginação diabólica", que por intermédio da perda do conceito de pecado e pela adoção de uma concepção de natureza humana infinitamente maleável e mutável, entende as normas morais como valores relativos às preferências individuais subjetivas ou à transitoriedade dos diferentes contextos culturais, defendendo a abolição de qualquer norma objetiva. Tanto a imaginação idílica quanto a imaginação diabólica tendem a defender a noção de 'liberdade enquanto

${ }^{22}$ GUROIAN, Vigen. A Imaginação Moral e os Contos de Fadas. Trad. e notas Márcia Xavier de Brito. COMMUNIO: Revista Internacional de Teologia e Cultura, Vol. XXVII, No. 1 (Ed. 97 / Jan.-Mar. 2008): 185-202. Cit. p. 190.

${ }^{23}$ KIRK, Russell. A Era de T. S. Eliot: A Imaginação Moral do Século XX. Apr. Alex Catharino, intr. Benjamin G. Lockerd Jr., trad. Márcia Xavier de Brito. São Paulo: É Realizações, 2011. p. 140.

${ }^{24}$ CATHARINO, Alex. A vida e a imaginação de Russell Kirk. In: KIRK, Russell. A Era de T. S. Eliot. p. 11-104. Cit. p. 82. 
poder', o que coloca tais formas de imaginário corrompido em oposição a qualquer postura que busque a preservação da 'liberdade interior' e da 'liberdade individual'.

Diante dos erros propagados pelas duas formas corrompidas de imaginário, o melhor antidoto é a imaginação moral, pois quando esta "se enriquece, as pessoas se percebem capazes de grandes coisas", no entanto, o empobrecimento desta percepção ética impossibilita a ação com eficácia e a "própria sobrevivência, a despeito da abundância de recursos materiais" 25 . Tendo como pontos de partida uma metáfora de Edmund Burke (1729-1797) para definir a moderna perda de religiosidade e do senso de cavalheirismo ${ }^{26}$, bem como algumas reflexões de John Henry Newman (1801-1890) ${ }^{27}$, de G. K. Chesterton (1874-1936) ${ }^{28}$, de Irving Babbitt (1865-1933) ${ }^{29}$, de T. S. Eliot (1888$1965)^{30}$ e de C. S. Lewis (1898-1963) ${ }^{31}$, Russell Kirk define a faculdade da imaginação moral como um "poder de percepção ética que atravessa as barreiras da experiência individual e de eventos momentâneos", e aspira "à apreensão da ordem correta na alma e da ordem correta na comuni-

${ }^{25}$ KIRK, Russell. A Arte Normativa e os Vícios Modernos. Trad. Gustavo Santos, notas Alex Catharino. COMMUNIO: Revista Internacional de Teologia e Cultura, Vol. XXVII, No. 4 (Ed. 100 / Out.-Dez. 2008): 993-1017. Cit. p. 993.

${ }^{26}$ BURKE, Edmund. Reflexões sobre a Revolução em França. Intr. Connor Cruise O'Brien; Trad. Renato de Assumpção Faria, Denis Fontes de Souza Pinto e Carmen Lídia Richter Ribeiro Moura. Brasília: Editora Universidade de Brasília, 1982. p. 101.

${ }_{27}$ NEWMAN, John Henry. Ensaio a Favor de uma Gramática do Assentimento. Trad. e apr. Artur Morão. Lisboa: Assírio \& Alvim, 2005.

${ }^{28}$ CHESTERTON, G. K. Ortodoxia. Apr., notas e anexo Ives Gandra da Silva Martins Filho, trad. Cláudia Albuquerque Tavares. São Paulo: Editora LTr, 2001. p. 69.

${ }^{29}$ BABBITT, Irving. Democracia e Liderança. Pref. Russell Kirk, trad. Joubert de Oliveira Brízida. Rio de Janeiro: Topbooks, 2003. p. 169.

${ }^{30}$ ELIOT, T. S. After Strange Gods: A Primer of Modern Heresy. Londres: Faber and Faber, 1934. p. 42.

${ }^{31}$ LEWIS, C. S. A Abolição do Homem. Trad. Remo Mannarino Filho. São Paulo: Martins Fontes, 2005. dade política" ao informar "sobre a dignidade da natureza humana"32.

A defesa da liberdade individual poderá ser reforçada com a adoção da noção de imaginação moral em análises de obras literárias e demais expressões artísticas, permitindo a apropriação do conteúdo simbólico de diferentes obras de arte como meio de melhor explicar, a partir de metáforas, determinados princípios éticos, políticos e econômicos. Em um longo artigo sobre a obra $O$ Senhor dos Anéis de J. R. R. Tolkien (1892-1973), tivemos a oportunidade de explicitar os princípios filosóficos, políticos e econômicos advogados pela Escola Austríaca a partir do conceito kirkeano de imaginação moral, discutindo de modo mais detido os fundamentos dessa noção $0^{33}$. No presente ensaio, apresentaremos em linhas gerais a filosofia da liberdade que perpassa a saga Star Wars, abordando a questão do gênero literário e dos fundamentos teóricos dos seis filmes produzidos até o momento, enfatizando a narratologia da jornada do herói / vilão Anakin Skywalker / Darth Vader, e, por fim, ressaltando algumas percepções éticas e políticas veiculadas pela série, destacando o problema moral da sedução pelo poder político.

\section{I - O GÊNERO E OS FundAMENTOS TEÓRICOS DE STAR WARS}

Diferente do que é defendido pela maioria dos críticos e analistas, acreditamos que a série Star Wars, não é, de fato, uma obra de ficção científica, no sentido estrito do

${ }^{32}$ KIRK, Russell. A Imaginação Moral. Trad. Gustavo Santos e notas Alex Catharino. COMMUNIO: Revista Internacional de Teologia e Cultura, COMMUNIO: Revista Internacional de Teologia e Cultura, Vol. XVIII, No. 1 (Ed. 101 / Jan.-Mar. 2009): 103-19. Cit. p. 104.

${ }^{33}$ CATHARINO, Alex. A Imaginação Moral de J. R. R. Tolkien e os Conceitos de Liberdade na Trilogia $O$ Senhor dos Anéis. MISES: Revista Interdisciplinar de Filosofia, Direito e Economia, Vol. I, No. 1 (Jan.-Jun. 2013): 215-54. 
gênero, visto que a narrativa e os valores defendidos são mais importantes do que o ambiente futurista do cenário das aventuras. $\mathrm{O}$ próprio George Lucas afirmou, numa entrevista no já citado documentário Empire of Dreams [Império dos Sonhos], que Star Wars é uma 'Space Opera' [Ópera Espacial]. Diferente do clássico filme 2001: Uma Odisseia no Espaço (1968) de Stanley Kubrick (1928-1999) ou dos livros de H. G. Wells (1866-1946) e de Isaac Asimov (1920-1992), que são modelos típicos de ficção científica 'hard', na qual o fator ciência é uma componente essencial da narrativa; os filmes da série Star Wars podem ser classificados, de modo semelhante às estórias da série Barsoom de Edgar Rice Burroughs (1875-1950), como uma aventura do gênero Space Opera, cujo conceito foi criado pelo escritor Wilson Tucker (1941-2006), em 1941, para definir um tipo de ficção científica 'soft', que enfatiza o aspecto dramático da narrativa e onde a tecnologia é utilizada apenas como um meio na luta entre o bem e o mal ${ }^{34}$. As duas trilogias de filmes Star Wars estão mais próximas, nesse sentido, do gênero de 'fantasia mitopoética' ${ }^{35}$, como as

\footnotetext{
${ }^{34}$ Além de Star Wars, podemos incluir nesse gênero as seguintes obras: 1) os livros da já citada série Barsoom de Edgar Rice Burroughs, composta por 11 volumes, publicados entre 1912 e 1943, dentre os quais se destacam a primeira trilogia, copilada nos livros A Princess of Mars [A Princesa de Marte], The Gods of Mars [Os Deuses de Marte] e The Warlord of Mars [O Comandante de Marte], que narram as aventuras da personagem John Carter; 2) as estórias em quadrinhos de Buck Rogers, criadas por Philip Francis Nowlan (1888-1940), e de Flash Gordon, criadas por Alex Raymond (1909-1956), bem como os filmes e seriados de TV inspirados nessas aventuras; e 3) os seriados de TV e os filmes da série Star Trek [Jornada nas Estrelas] de Gene Roddenberry (1921-1991).
}

${ }^{35}$ Utilizamos a definição de Marek Oziewicz, segundo a qual "a fantasia mitopoética é: 1) uma narrativa ficcional, 2) sobre aventuras de heróis psicologicamente humanos, 3) no mundo secundário - e, às vezes, também no mundo primário, 4) construídas a partir de uma variedade de materiais míticos artisticamente re-imaginados, apresentados como verdadeiros segundo critérios realistas, 5) e escritos para criar uma experiência imaginativa de um mundo onde os conceitos metafísicos são realidades objetivas - normalmente corporificados em personagens numinosas - e a resposta do protagonista aos dilemas morais e éticos pretendem mostrar séries O Senhor dos Anéis de J. R. R. Tolkien e As Crônicas de Nárnia de C. S. Lewis, do que das inúmeras obras, literárias ou cinematográficas, de ficção científica. O próprio George Lucas, numa entrevista para Paul Scanlon na revista Rolling Stones em agosto de 1977, afirma que ao fazer Star Wars ele:

Simplesmente quis esquecer a ciência, ela se basta por si só. Stanley Kubrick fez o filme máximo da ficção científica, e vai ser muito difícil para qualquer pessoa fazer um melhor. Queria uma fantasia espacial mais ao gênero de Edgar Rice Burroughs; toda aquela outra ponta de fantasia que existia antes de a ciência se sobrepujar, nos anos 1950. Uma vez que a bomba atômica chegou, todo mundo se interessou por monstros e pela ciência e com o que aconteceria com isso e com aquilo. Acho que a ficção especulativa é muito válida, mas se esqueceram dos contos de fadas e dos dragões e de Tolkien e de todos os heróis reais ${ }^{36}$.

A maioria das obras de ficção científica adotam um discurso utópico ou distópico ${ }^{37}$, o que transforma uma parcela significativa das produções desse gênero em um meio de propagação da imaginação idílica. A ficção científica foi definida por J. R. R. Tolkien como a "mais escapista de todas as formas literárias", pois, em muitos casos, os autores de tais obras tentam agir como verdadeiros profetas de uma Nova Era. Sobre o assunto, afirma Tolkien:

por que tais imperativos morais no mundo primário exigiriam determinados tipos de comportamento". Ver: OZIEWICZ, Marek. Prolegômenos à Fantasia Mitopoética. Trad. Márcia Xavier de Brito. COMMUNIO: Revista Internacional de Teologia e Cultura, Vol. XXVIII, No. 1 (Ed. 101 / Jan.-Mar. 2009): 121-49. Cit. p. 138.

36 "The Force Behind Star Wars". (An Interview with George Lucas by Paul Scanlon). Rolling Stones, 246 (August 25, 1977). Disponível em: http://www. rollingstone.com/news/story/7330268/the_force_ behind_star_wars

37 Para um aprofundamento acerca da temática, ver: FITTING, Peter. Utopia, Dystopia and Science Fiction. In: CLAEYS, Gregory (Ed.). The Cambridge Companion to Utopian Literature. Cambridge: Cambridge University Press, 2010. p. 135-53. 
Esses profetas frequentemente predizem (e muitos parecem ansiar por isso) um mundo como uma grande estação ferroviária de telhado de vidro. Mas para eles, em regra, é muito difícil deduzir que as pessoas farão numa cidade mundial como essa. Poderão abandonar a "plena panóplia vitoriana" em favor de trajes mais folgados (com zíperes), mas usarão essa liberdade principalmente, ao que parece, para brincar com brinquedos mecânicos no jogo de mover-se em alta velocidade, que logo satura. A julgar por alguns desses contos, ainda serão luxuriosos, vingativos e gananciosos como sempre, e os ideais de seus idealistas mal chegam além da esplêndida ideia de construir mais cidades do mesmo tipo em outros planetas. É de fato uma era de "meios aperfeiçoados para fins deteriorados". Faz parte da enfermidade essencial desses dias - produzindo o desejo de escapar, não de fato da vida, mas sim de nosso tempo presente e da miséria que nós mesmos fizemos - estarmos agudamente conscientes tanto da feiura de nossas obras quanto de seu mal. Assim, para nós o mal e a feiura parecem indissoluvelmente aliados. Achamos difícil conceber o mal e a beleza juntos ${ }^{38}$.

De modo algum a crítica tolkieniana pode ser aplicada à saga criada por George Lucas, visto que ao compararmos Star Wars com a maioria das obras de ficção científica, principalmente aos filmes do gênero produzidos nas décadas de 1950 a 197039,

${ }^{38}$ TOLKIEN, J. R. R. Sobre Histórias de Fadas. Trad. Ronald Kyrmse. São Paulo: Conrad, 2006. p. 72-73.

39 Dentre as principais produções do período, destacamos os filmes: O Dia em que a Terra Parou (1951) de Robert Wise (1914-2005), Guerra dos Mundos (1954) de Byron Haskin (1899-1984), Invasores de Corpos (1956) de Don Siegel (1912-1991), O Planeta Proibido (1956) de Fred Wilcox (1907-1964), Alphaville (1965) de Jean-Luc Godard, Fahrenheit 451 (1966) de François Truffaut (1932-1984), o já citado 2001: Uma Odisséia no Espaço (1968) de Stanley Kubrick, Barbarella (1968) de Roger Vadin (1928-2000), O Planeta dos Macacos (1968) de Franklin Schaffner (1920-1989), De volta ao Planeta dos Macacos (1970) de Ted Post (1918-2013), THX 1138 (1971) do próprio George Lucas, Fuga do Planeta dos Macacos (1971) de Don Taylor (1920-1998), A Laranja Mecânica (1971), também, de Stanley Kubrick, Solaris encontramos algumas inovações significativas, a saber:

$\left.1^{a}\right)$ O abandono da obsessão pelo futuro, visto que todos os filmes da série começam com a epigrama: "Há muito tempo, em uma galáxia muito, muito distante..." [A long time ago in a galaxy far, far away...];

$\left.2^{a}\right)$ A recuperação do arquétipo do herói dotado de valores morais elevados e obediente a um código de honra objetivo. Diferente dos protagonistas da maioria dos filmes de ficção científica, pessoas "neutras" que agem somente em resposta aos acontecimentos externos com que se deparam, os heróis de Star Wars se assemelham aos protagonistas de sagas clássicas da literatura ocidental;

3a) A objetividade do mal, personificada em indivíduos degenerados e decaídos. Em Star Wars o mal é uma ausência do bem e, ao mesmo tempo, o fruto de escolhas individuais de sujeitos dotados de livre arbítrio, que, para obter o poder ou saciar seus desejos pessoais, optam por um caminho mais fácil em detrimento às normas objetivas de um código moral pautado na tradição;

$\left.4^{a}\right)$ O caráter pedagógico da narrativa como meio de busca da felicidade mútua, pois o próprio George Lucas assume publicamente que quando faz um filme está ensinando milhares de joven s como devem se conduzir, o que o faz se sentir responsável com os valores veiculados em sua obra. Para o cineasta norte-americano um dos temas principais de Star Wars é fazer as pessoas compreenderem que devem viver colaborando com outros seres humanos e demais organismos vivos, para o benefício mútuo de toda a criação;

5ª) A importância do mito, a busca pelos valores da tradição e a universalidade da mensagem, pois George Lucas, de forma consciente, recriou na saga Star Wars os temas clássicos, extraindo as normas morais fundamentais comuns de diferentes mitologias e crenças religiosas, para criar uma mensagem universal para culturas distintas.

(1972) de Andrei Tarkovski (1932-1986), A Conquista do Planeta dos Macacos (1972) e A Batalha do Planeta dos Macacos (1973) de John Lee Thompson (1914-2002), No Mundo de 2020 (1973) de Richard Fleischer (1916-2006) e Zardoz (1974) de John Boorman. 
Nesse processo, os mitos são um importante meio das pessoas encontrarem a própria individualidade e entenderem seu devido lugar no mundo, lembrando que cada indivíduo faz parte de algo maior, que transcende o mero auto-interesse ${ }^{40}$.

Os fundamentos que servem de base para tais inovações da série Star Wars se encontram nos profundos estudos que George Lucas fez sobre a teoria da 'narratologia do monomito' de Joseph Campbell (1904-1987). Podemos definir, em linhas gerais, a narratologia do monomito como a teoria semiótica defensora da hipótese de que todos os mitos, as lendas, os épicos e as narrativas sagradas das diferentes culturas se referem essencialmente a uma mesma história. A concepção de 'monomito' de Campbell têm suas bases no conceito de 'arquétipo', desenvolvido pela psicologia analítica de Carl Jung (18751961), na noção de 'forças inconscientes', tal como proposta pela psicanálise de Sigmund Freud (1856-1939), e na concepção de 'ritos de passagem', segundo as análises antropológicas de Arnold van Gennep (1873-1957), tendo aparecido pela primeira vez, em 1949, na obra The Hero with a Thousand Faces [O Herói de Mil Faces ${ }^{41}$. Em uma entrevista para seu discípulo, o jornalista Bill Moyer, Joseph Campbell afirma que:

Existe uma certa sequência de ações heroicas, típica, que pode ser detectada em histórias provenientes de todas as partes do mundo, de vários períodos da história. $\mathrm{Na}$ essência, pode-se até afirmar que não existe senão um herói mítico arquetípico, cuja vida se multiplicou em réplicas, em muitas terras, por muitos, muitos povos. Um herói lendário é normalmente o fundador de algo, o fundador de uma nova era, de uma nova religião, uma nova cidade, uma nova modalidade de vida. Para fundar algo novo ele deve, ele deve abandonar o velho e partir

${ }^{40}$ CATHARINO. A Imaginação Moral em Star Wars. p. 227-28.

${ }^{41}$ CAMPBELL, Joseph. O Herói de Mil Faces. Trad. Adail Ubirajara Sobral. São Paulo: Editora Pensamento, 11를. 1995. em busca da ideia-semente, a ideia germinal que tenha a potencialidade de fazer aflorar aquele algo novo ${ }^{42}$.

Segundo Joseph Campbell, em O Herói de Mil Faces, a jornada do herói é composta necessariamente por três etapas principais, cada uma delas com fases distintas, a saber:

1ª) A Partida, quando o herói sai do mundo comum e parte para a aventura, iniciando a jornada ${ }^{43}$;

$2^{a}$ ) A Iniciação, etapa onde o herói vive as principais aventuras da jornada e, ao mesmo tempo, aprofunda seu aprendizado, recebendo novos poderes e resolvendo conflitos internos ${ }^{44}$;

$3^{a}$ ) O Retorno, quando o herói volta para o mundo comum com o conhecimento e os poderes que adquiriu ao longo da jornada ${ }^{45}$.

As jornadas específicas de diferentes heróis, narradas em diversos mitos, não necessitam seguir, de forma rígida, o esquema elaborado por Joseph Campbell. $\mathrm{Na}$ realidade, acreditamos que nenhuma estória abrange todas as diferentes fases das três etapas principais. O modelo ideal apresentado pela teoria da narratologia do monomito serve para orientar um caminho seguro de compreensão de várias mitologias ou para criar narrativas duradouras, que tratem de temas fundamentais. Tal esquema explicativo adotado por Campbell é portador de inúmeros aspectos problemáticos, o que parece ser inerente aos diversos estudos "perenialistas" de religião comparada, que de alguma forma substituem a casuística histórica do fato concreto pela busca de modelos ideais generalizantes ${ }^{46}$. No entanto, os erros teológicos, históricos e literários contidos nas

${ }^{42}$ CAMPBELL, Joseph \& MOYERS, Bill. O Poder do Mito. Org. Betty Sue Flowers; Trad. Carlos Felipe Moisés. São Paulo: Palas Athena, 1992. p. 145.

${ }^{43}$ CAMPBELL. O Herói de Mil Faces. p. 59-94.

${ }^{44}$ Idem. Ibidem., p. 102-79.

${ }^{45}$ Idem. Ibidem., p. 195-236.

${ }^{46}$ Apresentamos algumas críticas aos erros teológicos nos estudos de Joseph Campbel em: CATHARINO. A Imaginação Moral em Star Wars. p. 230-32. 
teorias de Campbell não invalidam os conteúdos de verdade semiótica e moral presentes na análise da narratologia do monomito, principalmente como aparato teórico para a elucidação das estruturas de enredo das modernas produções cinematográficas ${ }^{47}$.

No que tange à criação de obras cinematográficas, a proposta de Joseph Campbell foi o fundamento de alguns sucessos de bilheteria. Além de ter servido como matriz teórica da saga Star Wars de George Lucas, as ideias expostas em $O$ Herói de Mil Faces foi a base do, agora lendário, A Practical Guide to The Hero With a Thousand Faces [Um Guia Prático para o Herói de Mil Faces], um memorando corporativo interno de sete páginas, elaborado por Christopher Vogler, para os roteiristas dos estúdios Disney, que deu origem a nove longas-metragens de animação que marcam o denominado período 'Disney Renaissance' [Renascimento da Disney $]^{48}$. A partir desse memorando, Vogler escreveu o livro The Writer's Journey: Mythic Structure For Writers [A Jornada do Escritor: Estrutura Mítica para Escritores] ${ }^{49}$, publicado originalmente em

\footnotetext{
${ }^{47} \mathrm{~A}$ análise de cinquenta filmes de diferentes gêneros tendo como fundamento as teorias de Joseph Campbell é apresentada na seguinte obra: VOYTILLA, Stuart. Myth and the Movies: Discovering the Mythic Structure of 50 Unforgettable Films. Foreword by Christopher Vogler. Studio City: Michael Wise Productions, 1999.
}

${ }^{48}$ O estúdio de animação fundado, em 1923, por Walt Disney (1901-1966) foi responsável pela criação dos mais famosos e bem-sucedidos desenhos animados de toda a história do cinema. Entretanto, ao longo da década de 1980, a Walt Disney Company recebeu críticas negativas e bilheterias abaixo do esperado. O memorando de Christopher Vogler foi a base de uma fórmula de sucesso que revigorou a Disney, criando um 'renascimento' dos estúdios, numa nova fase de críticas positivas e altas bilheterias com os longas-metragens de animação: The Little Mermaid [A Pequena Sereia] de 1989, Beauty and the Beast [A Bela e a Fera] de 1991, Aladdin de 1992, The Lion King [O Rei Leão] de 1994, Pocahontas de 1995, The Hunchback of Notre Dame [O Corcunda de Notre Dame] de 1996, Hercules [Hércules] de 1997, Mulan de 1998, e Tarzan de 1999.

49 VOGLER, Christopher. A Jornada do Escritor: Estruturas Míticas para Escritores. Pref. e trad. Ana
1990, que serviu como modelo para os irmãos Andy Wachowski e Larry Wachowski criarem a trilogia Matrix. Junto com as teorias de Campbell, a saga Star Wars exerceu influência significativa no desenvolvimento das propostas de Voegler, que afirma:

[...] devo reconhecer o impacto duradouro provocado pela série Guerra nas Estrelas. O filme Guerra nas Estrelas [Uma Nova Esperança] foi lançado [em 1977] quando eu estava começando a digerir as ideias de Joseph Campbell e se revelou uma expressão inteiramente desenvolvida de seu conceito de Jornada do Herói. O filme me ajudou a elaborar a teoria e testar minhas próprias ideias. E logo se tornou um desses eventos cinematográficos de suma importância, quebrando recordes e estabelecendo padrões mais elevados para os filmes. Quando comecei a ensinar "estrutura mítica", Guerra nas Estrelas me forneceu um exemplo conveniente e amplamente conhecido para demonstrar os movimentos e princípios da Jornada do Herói, no qual as funções das partes eram simples, nítidas e vívidas. $\mathrm{O}$ filme usou linguagem comum da cultura pop, oferecendo metáforas, símbolos e frases úteis que exprimiam como nos sentimos em relação ao bem e ao mal, à tecnologia e à fé. A película gerou uma indústria bilionária de continuações, acessórios, franquias e objetos de coleção. Gerações inteiras cresceram sob sua influência e o filme inspirou inúmeros artistas a pensarem com maior ousadia e perseguirem seus sonhos de criatividade. Como ocorreu com os velhos mitos, o filme preencheu as mesmas funções para milhões de pessoas, oferecendo padrões comparativos, fornecendo metáforas e significados.

Se Guerra nas Estrelas [Uma Nova Esperança] fosse um filme sem sequências, seu impacto cultural ainda seria considerável, mas sua influência foi triplicada pela continuação da série com O Império Contra-Ataca e O Retorno de Jedi ${ }^{50}$.

Do ponto de vista artístico, as produção cinematográficas, mesmo as mais populares

Maria Machado. Rio de Janeiro: Nova Fronteira, $2^{\mathrm{a}}$ Ed., 2006.

${ }^{50}$ Idem. Ibidem., p. 427-28. 
destinadas ao público massificado, não devem ser subestimadas como gênero de categoria inferior, como o fazem algumas análises elitistas, pois estas, assim como as tragédias de William Shakespeare (1564-1616) e as óperas de Wolfgang Amadeus Mozart (1756-1791) são, de certo modo, as produções culturais que respondem melhor aos anseios de individualidade característicos do ethos burguês moderno $^{51}$. O crítico literário Northrop Frye (1912-1991), descreve a forma específica do drama cinematográfico como uma "máscara ideal" que "tende a individualizar seu público ao apontar para seu membro central", ressaltando que "até mesmo o público de cinema, sentado no escuro, em pequenas unidades (geralmente a dois) é em geral individualizado" ${ }^{52}$. Na percepção do renomado crítico canadense:

Tanto a ópera quanto o cinema são, como a máscara, proverbiais pela exibição excessiva, e parte da razão para isso, no cinema, é que muitos filmes, são, na verdade, peças de mito burguesas, como meia dúzia de críticos subitamente, e quase simultaneamente, descobriram alguns anos atrás. [...]

A ópera e o cinema possuem, ao contrário da máscara, o poder de produzir imitações espetaculares do drama mimético. A ópera somente pode fazer isso simplificando sua organização musical; caso contrário, sua estrutura dramática será borrada pela distorção da atuação que a estrutura alta-

${ }^{51}$ Sobre a temática, ver: HAYEK, F. A. Individualism: True and False. In: Individualism and Economic Order. University of Chicago Press, 1948. p. 1-32; ELIAS, Norbert. A Sociedade dos Indivíduos. Org. Michael Schröter; Trad. Vera Ribeiro; Rev. tec. e notas Renato Janine Ribeiro. Rio de Janeiro: Jorge Zahar Editor, 1994. Ver, também: WATT, Ian P. Mitos do Individualismo Moderno: Fausto, Dom Quixote, Dom Juan, Robinson Crusoé. Trad. Mario Pontes. Rio de Janeiro: Jorge Zahar, 1997; HOLBROOK, Peter. Shakespeare's Individualism. Cambridge: Cambridge University Press, 2013; ELIAS, Norbert. Mozart: Sociologia de um Gênio. Org. Michael Schröter; Trad. Sérgio Góes de Paula; Rev. tec. Renato Janine Ribeiro. Rio de Janeiro: Jorge Zahar Editor, 1995.

52 FRYE, Northrop. Anatomia da Crítica: Quatro Ensaios. Pref. Robert D. Denham; Pref. Ed. Br. João Cezar de Castro Rocha; Trad. Marcus de Martini. São Paulo: É Realizações, 2014. p. 451. mente repetitiva da música torna necessária. De forma semelhante o cinema precisa simplificar seu espetáculo. À proporção em que segue sua inclinação natural pela organização cênica, o cinema revela suas afinidades com outras formas da máscara cênica [...]. Quando o cinema tem sucesso em imitar um drama mimético, a distinção entre as duas formas não vale a pena ser feita, mas a diferença genérica mostra-se de vários modos. $\mathrm{O}$ drama mimético trabalha em razão de um final que ilumina o início, por estar logicamente conectado a ele: e por isso, a forma parabólica da típica estrutura mimética de cinco atos, e por isso a qualidade ideológica expressa pelo termo "reconhecimento". O drama espetacular, por outro lado, é por natureza processionário, e tende a um reconhecimento episódico e gradativo, como podemos ver em todas as formas de espetáculo puro, do desfile de circo ao teatro de revista ${ }^{53}$.

Entendemos que os seis episódios da saga Star Wars, quando vistos em conjunto como uma única estória, conseguem unir na mesma obra as estruturas do drama mimético e do drama espetacular. De acordo com Northrop Frye, a importância central no cinema é a "sensação de ver a mimese dramática em meio a uma névoa de arrebatamento espetacular" ${ }^{54}$. Além de congregar em sua criação os aspectos mimético e espetacular, outro grande mérito artístico de George Lucas é o de assumir o ideal estético exposto por Platão (427-347 a.C.), de acordo com o qual "é de um mesmo homem o saber fazer uma comédia e uma tragédia, e que aquele que com arte é um poeta trágico é também um poeta cômico"55. A respeito desse ideal platônico, Frye afirma que os autores "que fizeram

\footnotetext{
${ }^{53}$ Idem, Ibidem., p. 448-49.

${ }^{54}$ Idem, Ibidem., p. 449.

${ }^{55}$ PLATÃO. O Banquete, 223b. Utilizamos a passagem da seguinte edição brasileira: PLATÃO. O Banquete. Trad. José Cavalcante de Souza. In: Diálogos: Banquete - Fédon - Sofista - Político. São Paulo: Abril Cultural, 1972. (Coleção “Os Pensadores”, Volume III: Platão). p. 7-59. Cit. p. 59.
} 
isso com maior sucesso foram aqueles que como Shakespeare e Mozart, tiveram um forte interesse por formas espetaculares" ${ }^{15}$. A épica Space Opera garantiu ao cineasta norte-americano um lugar ao lado do dramaturgo inglês e do compositor austríaco, pois George Lucas foi um dos poucos artistas que conseguiu unir o mimético e o espetacular. Transitando entre os gêneros trágico e cômico, a aventura narrada em Star Wars é um grandioso espetáculo animado por efeitos especiais sofisticados e por uma trilha sonora orquestral que transformam o filme, de fato, em uma ópera, ao mesmo tempo em que não descuida da dramaticidade mimética, que pode ser apropriada como um importante elemento pedagógico pelos defensores da liberdade.

\section{II - A Tragédia de ANAKIN SKYWALKer / DARTH VADER}

A trilogia original de Star Wars, composta pelos episódios IV, V e VI, narram, principalmente, as aventuras de Luke Skywalker ${ }^{57}$, um jovem fazendeiro órfão, que após encontrar o sábio ancião Obi-Wan Kenobi, um mestre Jedi, descobriu que o seu pai havia sido um cavalheiro Jedi, aprendeu sobre a "Força", se tornou membro da Aliança Rebelde e, junto com o contrabandista Obi-Wan, resgatou a princesa Leia Organa, que era prisioneira do Império Galáctico na Estrela da Morte, uma poderosa estação de batalha capaz de destruir um planeta. Durante a missão de resgate Obi-Wan é morto numa luta de "sabre de luz" contra Darth Vader, seu antigo aprendiz que foi seduzido pelo "Lado Negro" da Força. Finalmente, em uma desesperadora batalha espacial dos rebeldes contra a Estrela da Morte, Luke ao confiar na Força conseguiu destruir essa estação militar, se

\footnotetext{
${ }^{56}$ FRYE. Anatomia da Crítica. p. 450.

${ }^{57}$ Uma análise da jornada de Luke Skywalker de acordo com o esquema das teorias da narratologia do monomito, ver: VOYTILLA. Myth and the Movies. p. 290-91.
}

tornando um dos líderes da Aliança Rebelde ${ }^{58}$. Após receber treinamento Jedi, por indicação do espírito de Obi-Wan, com o Mestre Yoda, Luke travou, pela primeira vez, uma luta com sabre de luz contra Vader, que, após derrotar o jovem, revelou ser o seu pai ${ }^{59}$. Yoda, antes de morrer, confirmou que Darth Vader foi Anakin Skywalker, o pai de Luke. O espírito de Obi-Wan revelou que Leia é irmã de Luke e que os rebeldes serão vitoriosos na luta contra o Império somente se o jovem destruir Vader e seu mestre, o Imperador Palpatine. Durante uma missão da Aliança Rebelde para destruir uma nova Estrela da Morte, Luke abandonou o grupo e se entregou a Vader, por acreditar que, no pai-vilão ainda existia o bem e que poderia redimi-lo. Ao encontrar o pai, buscou convencê-lo a abandonar o caminho das trevas, mas Vader rejeitou o pedido do filho e o levou para o Imperador, que tentou, sem sucesso, corromper Luke, assim como fizera com Anakin. Quando Luke descobriu o plano de Palpatine para esmagar definitivamente a Aliança Rebelde, tentou matá-lo, mas foi impedido por Vader. Finalmente, Luke derrotou o pai numa luta de sabre de luz e se recusou a matá-lo, causando a fúria do Imperador que o atacou, mas Darth Vader salvou o filho, matando Palpatine, e, redimido, morreu nos braços do filho. Luke, após fazer um funeral Jedi para o pai, teve a certeza de ter salvado a alma de Anakin, ao ver o espírito dele junto aos espíritos de Obi-Wan e Yoda ${ }^{60}$.

${ }^{58}$ Ver o filme Star Wars: Episódio IV - Uma Nova Esperança. Ver, também, o livro: LUCAS, George. Star Wars: Episode IV - A New Hope. New York: Ballantine Books, 1976. Para uma análise do filme de acordo com o esquema das teorias da narratologia do monomito, ver: VOYTILLA. Myth and the Movies. p. 274-78.

${ }^{59}$ Ver o filme Star Wars: Episódio V - O Império ContraAtaca. Ver, também, o livro: GLUT, Donald F. Star Wars: Episode V - The Empire Strikes Back. (Based on the story by George Lucas and the screenplay by Leigh Brackett and Lawrence Kasdan). New York: Ballantine Books, 1980. Para uma análise do filme de acordo com o esquema das teorias da narratologia do monomito, ver: VOYTILLA. Myth and the Movies. p. 279-84.

${ }^{60}$ Ver o filme Star Wars: Episódio VI - O Retorno de Jedi. Ver, também, o livro: KAHN, James. Star Wars: 
A figura de Darth Vader se transformou numa das mais fortes imagens do mal em nossa cultura. Ele é um homem mutilado, que vive com o apoio de um traje mecânico, uma assustadora armadura negra, e com o rosto oculto por uma máscara igualmente negra, que produz a característica respiração mecânica, além de usar um capacete e uma capa negros. O símbolo de Darth Vader no imaginário contemporâneo e tão forte, que a personagem foi classificada, pela lista da American Film Institute, como o terceiro maior vilão cinematográfico de todos os tempos ${ }^{61}$. Sobre o impacto cultural de sua criação, George Lucas declarou:

Darth Vader se tornou um símbolo no primeiro filme, o Episódio IV, e esse símbolo do mal subjugou todas as minhas intenções. Se fosse um filme só, isso não teria acontecido. Ele seria revelado como uma figura patética ao final do filme. Mas agora, acrescentando os episódios I, II e III, as pessoas começam a ver a tragédia de Darth Vader, como era minha intenção original ${ }^{62}$.

George Lucas expõe sua verdadeira intenção sobre a personagem Darth Vader com as seguintes palavras:

Os filmes foram planejados como um só filme. Ele começa com a tragédia de Darth Vader. Era para ser um só filme, o Episódio IV. Você não saberia o que viria depois, nem

Episode VI - Return of Jedi. (Based on the story by George Lucas and the screenplay by Lawrence Kasdan and George Lucas). New York: Ballantine Books, 1983. Para uma análise do filme de acordo com o esquema das teorias da narratologia do monomito, ver: VOYTILLA. Myth and the Movies. p. 285-89.

${ }^{61}$ Darth Vader, nesta lista que escolheu os cinquenta maiores vilões cinematográficos de todos os tempos, só perdeu para as personagens Dr. Hannibal Lecter, de Anthony Hopkins, em O Silêncio dos Inocentes de Jonathan Demme, e Norman Bates, de Anthony Perkins (1932-1992), em Psicose de Alfred Hitchcock (1899-1980). A lista completa está disponível em: http:// www.afi.com/tvevents/100years/handv.aspx

${ }^{62}$ Declaração feita no documentário The Chosen One [O Escolhido], de 2005, dirigido por Tippy Bushkin, que aparece como um dos extras do segundo disco da edição de DVD dupla do filme A Vingança dos Sith. o que veio antes. Para escrever o roteiro, precisei criar uma história passada, que dizia quem era cada personagem, de onde vinha. O subtítulo do filme era A Tragédia de Darth Vader. Começava com esse monstro aparecendo, empurrando todo mundo, ameaçando, estrangulando pessoas. $\mathrm{Na}$ metade do filme você descobre que o monstro é um homem. É o pai do herói. E, no final do filme, você descobre que o filho inspira o monstro, ou o pai, a ser o herói do filme e que ele tem vivido essa vida terrível, preso no traje, porque vendeu sua alma ao Diabo. Tudo isso deveria ser mais forte do que era, mas acabei dividindo em três partes. O símbolo de Darth Vader tornou-se tão forte como o símbolo do mal, que era difícil pensar nele como uma personagem trágica. Foi uma das coisas que me levou a fazer os três primeiros episódios, para dar uma ideia melhor de toda a história. Mas agora com a última peça em seu lugar, espero que pensem em tudo isso como um só filme e não como seis pequenos filmes, mas como um filme longo sobre a tragédia de Darth Vader, que era a intenção original ${ }^{63}$.

Ao assistir os filmes na ordem correta, podemos compreender a jornada de Anakin Skywalker, sua tragédia, ao se transformar em Darth Vader, e sua redenção, pela jornada de Luke Skywalker. Anakin era um jovem escravo, misteriosamente gerado sem a existência de um pai e encontrado por Qui-Gon Jinn, um Mestre Jedi, que, após verificar nele uma presença da Força acima da média, passou a acreditar que o menino era "o Escolhido" anunciado por uma antiga profecia Jedi. Ao vencer uma perigosa corrida de "naves" no deserto, o jovem Anakin ajuda o mestre Qui-Gon Jinn e seu aprendiz Obi-Wan Kenobi a sair do desértico planeta Tatooine para completar a missão diplomática que transportava a rainha Amidala do planeta Naboo até o planeta Coruscant, capital da República Galáctica. Qui-Gon levou Anakin na viagem com o intuito de apresenta-lo ao Conselho Jedi, que, num primeiro momento,

\footnotetext{
${ }^{63}$ Declaração feita nos comentários de áudio ao filme $A$ Vingança dos Sith.
} 
recusou o pedido de dar treinamento ao jovem, porque Mestre Yoda sentiu sua vulnerabilidade diante do medo e viu que o futuro de Anakin era incerto. Anakin acompanhou Qui-Gon, Obi-Wan e a Princesa Amidala na missão de libertação de Naboo, que estava sob o domínio da Federação de Comércio. Na missão de resgate, Anakin participou involuntariamente de uma batalha espacial e conseguiu destruir a estação de combate dos adversários que controlavam os exércitos de androides, garantindo a vitória das forças de Naboo. Após a morte de Qui-Gon num combate de sabre de luz com Darth Maul - um Sith (seguidores do Lado Negro da Força) aprendiz do manipulador Darth Sidious -, ficou decidido que Anakin receberia treinamento Jedi de Obi-Wan Kenobi, o discípulo do finado Mestre Jedi ${ }^{64}$. Anakin Skywalker, ainda em treinamento, se apaixonou pela senadora Padmé Amidala, o que era proibido, pois a Ordem Jedi era celibatária. Contudo, Anakin casou secretamente com a senadora ${ }^{65}$. O medo de que a esposa grávida morresse durante o parto, aliado ao orgulho e aos desejos de alcançar mais poderes, possibilitou ao Chanceler Palpatine seduzir Anakin e o transformar em Darth Vader. Na verdade Palpatine era Darth Sidious, um Lorde Sith, que com o apoio de Darth Vader destruiu a Ordem Jedi e ajudou implantou o tirânico Império Galáctico. Após uma luta de sabres de luz, em que foi derrotado por Obi-Wan, Vader ficou mutilado e foi obrigado a viver dentro do traje mecânico, servindo ao Imperador Palpatine e sofrendo pela morte da esposa e do filho ${ }^{66}$. Vinte anos após a transfor-

${ }^{64}$ Ver o filme Star Wars: Episódio I - A Ameaça Fantasma. Ver, também, o livro: BROOKS, Terry. Star Wars: Episode - I The Phantom Menace. (Based on the screenplay and story by George Lucas). New York: Ballantine Books, 1999.

${ }^{65}$ Ver o filme Star Wars: Episódio II - Ataque dos Clones. Ver, também, o livro: SALVATORE, S. A. Star Wars: Episode II - Attack of the Clones. (Based on the story and screenplay by George Lucas). New York: Ballantine Books, 2002.

${ }^{66}$ Ver o filme Star Wars: Episódio III - A Vingança dos Sith. Ver, também, o livro: STOVER, Matthew. Star Wars: Episode III - Revenge of the Sith. (Based on mação em Vader, finalmente, conseguiu matar Obi-Wan numa luta com sabres de luz, quando o antigo mestre tentava resgatar a Princesa Leia Organa, líder da Aliança Rebelde, mas não conseguiu impedir que o novo discípulo do antigo mestre destruísse a Estrela da Morte ${ }^{67}$. Ao descobrir que o jovem que destruiu a estação de combate era o filho de Anakin com Padmé, escondido por Yoda e Obi-Wan, Vader tentou capturar Luke, seduzi-lo para o Lado Negro da Força, revelando que era seu pai, e, com o apoio dele, tomar o lugar do Imperador Palpatine ${ }^{6}$. Percebendo que Luke era forte demais para ser seduzido apenas por ele, Vader levou o filho para o Imperador, que secretamente desejava colocar o jovem no lugar do pai. Após ser derrotado por Luke, Vader testemunha o sofrimento do filho, que é atacado pelo Imperador Palpatine, e resolve salvar o jovem, voltando a ser Anakin Skywalker e matando o Lorde Sith ${ }^{69}$. Esta dramática saga de Anakin Skywalker é resumida por George Lucas com as seguintes palavras:

Ao assistir ao filme na ordem correta, a história esclarecerá que Anakin é "o Escolhido". Mesmo quando Anakin se transforma em Darth Vader, ele ainda é o escolhido [...]. A profecia é que Anakin equilibrará a Força e destruirá os Sith. Ele se torna Darth Vader. Darth Vader se torna o herói. Darth Vader destrói os Sith, ou seja, ele mesmo e o Imperador. Ele faz isso porque é redimido por seu filho. Então a profecia é real. Fazendo isso ele se redime, deixa de ser Darth Vader e volta a ser Anakin ${ }^{70}$.

the screenplay and story by George Lucas). New York: Ballantine Books, 2005.

${ }^{67}$ Ver o filme Star Wars: Episódio IV-Uma Nova Esperança. Ver, também, o livro: LUCAS. Star Wars: Episode IV A New Hope.

${ }^{68}$ Ver o filme Star Wars: Episódio V - O Império ContraAtaca. Ver, também, o livro: GLUT. Star Wars: Episode V - The Empire Strikes Back.

${ }^{69}$ Ver o filme Star Wars: Episódio VI - O Retorno de Jedi. Ver, também, o livro: KAHN. Star Wars: Episode VI Return of Jedi.

${ }^{70}$ Declarações feitas no, já citado, documentário The Chosen One. 
O criador da saga defende que esta é " $a$ história da redenção de Darth Vader". É a jornada de uma pessoa que acreditávamos ser o vilão, mas que na verdade é a vítima. É uma história "sobre o vilão tentando recuperar sua humanidade". George Lucas continua o seu comentário, afirmando que: "Todos imaginavam Darth Vader como um vilão sem coração, que era simplesmente mau. Mas no fim não é nada disso, ele é, apenas, alguém que perdeu tudo"71. Nesses termos é possível afirmar Anakin Skywalker encarna o arquétipo do herói trágico. De acordo com Aristóteles (384-322 a.C.):

O elemento mais importante é a trama dos fatos, pois a tragédia não é imitação de homens, mas de ações de vida, de felicidade e infelicidade; mas felicidade ou infelicidade, reside na ação, e a própria vida é uma ação, não uma qualidade. Ora, os homens possuem tal ou tal qualidade conforme o caráter, mas são bem ou mal-aventurados pelas ações que praticam. Daqui se segue que, na tragédia não agem as personagens para imitar caracteres, mas assumem caracteres para efetuar certas ações; por isso as ações e o mito constituem a finalidade da tragédia, e a finalidade é tudo o que mais importa.

Sem ação não poderia haver tragédia, mas poderia havê-la sem caracteres ${ }^{72}$.

Ecoando a teoria poética aristotélica, Christopher Voegler ressalta uma falha moral característica dos heróis trágicos, que ajuda a entender melhor o problema da queda de Anakin Skywalker. Esse vício intrínseco dos heróis trágicos é o que leva tais personagens à destruição, apesar das inúmeras qualidades que possuem, pois os coloca em confronto com o destino pessoal, ou com outros homens, ou com os deuses. De acordo com Voegler:

${ }^{71}$ Comentários, também, retirados do documentário The Chosen One.

${ }^{72}$ ARISTÓTELES. Poética, 1420a. Utilizamos a passagem da seguinte edição brasileira: ARISTÓTELES. Poética. Trad. Eudoro de Souza. São Paulo: Abril Cultural, 1973. (Coleção "Os Pensadores", Volume IV: Aristóteles). p. 237-310. Cit. p. 246.
Na maioria das vezes, essa falha trágica é uma espécie de orgulho ou arrogância, chamada hybris. Os heróis trágicos, frequentemente, são pessoas superiores, com poderes extraordinários, mas tendem a se considerar iguais aos deuses, ou até melhores que eles. Ignoram advertências sensatas ou desafiam os códigos morais locais, achando que estão acima das leis divinas e humanas. Essa soberba é fatal, acaba, inevitavelmente o nome de uma deusa da retribuição, cujo trabalho era reequilibrar as coisas, geralmente por meio da destruição do herói trágico. ${ }^{73}$.

A relação, criada por George Lucas, entre a queda de um herói, que se torna o vilão, com a implantação de um regime tirânico e sua redenção com o fim dessa ditadura, não é uma mera figura literária "eucatástrofica" nos moldes de J. R. R. Tolkien ${ }^{74}$. Muitas vezes, levados, de forma inconsciente, ao esquecimento de que a singularidade da pessoa se manifesta em diferentes campos da ação humana e, como destaca Russell Kirk, não recordam que as desordens institucionais que nos cercam são, na verdade, reflexo da desordem espiritual dos indivíduos ${ }^{75}$. Da mesma forma que o mal pode ser decorrente da ação de um único indivíduo, a redenção poderá ser obra de um único homem. Devemos sempre ter em mente as palavras de São Paulo, o Apóstolo, na Epístola aos Romanos, quando, ao tratar de Adão e de Jesus Cristo, afirma que: Assim como pela falta de um só resultou a condenação de todos os homens, do mesmo modo, da obra de justiça de um só, resultou

\footnotetext{
${ }^{73}$ VOGLER. A Jornada do Escritor. p. 151.
}

${ }^{74} \mathrm{O}$ autor da série $\mathrm{O}$ Senhor dos Anéis, J. R. R. Tolkien, denominava "eucatástrofe" o ponto, improvável e ao mesmo tempo verdadeiro, numa narrativa, quando tudo parece perdido e, uma inesperada virada, garante um final feliz. Tolkien afirma que a eucatástrofe "nega a derrota final universal, e nessa medida é evangelium, dando um vislumbre fugaz da Alegria, Alegria além das muralhas do mundo, pungente como o pesar" (TOLKIEN. Sobre Histórias de Fadas. p. 77).

75 KIRK, Russell. The Roots of American Order. Edited with a New Foreword by Forrest McDonald. Wilmington: ISI Books, $4^{\text {th }}$ Ed., 2003. p. 5. 
para todos os homens justificação que traz a vida. De modo que, como pela desobediência de um só homem, todos se tornaram pecadores, assim pela obediência de um só, todos se tornarão justos $(\operatorname{Rm} 5,18-19)^{76}$.

As modernas sociedades marcadas por um espectro ideológico que se volta contra a ordem interna e a liberdade individual são assombradas pela ansiedade, produzida tanto pela "desordem na existência privada" quanto pela "desordem na experiência social", que cresce "na fraqueza, impotência e frustração" e, apesar de nunca poder ser totalmente abolida, só recuará quando estivermos em conformidade com as normas morais fundadas em uma antropologia adequada, recuperando, assim, "o propósito da existência do homem"77. O fio condutor da jornada tanto do herói / vilão Anakin Skywalker / Darth Vader quanto do herói Luke Skywalker é uma metáfora dessa busca pelas normas que permitem a pessoa viver em equilíbrio com a realidade que a cerca, superando os limites externos impostos por forças malignas. Na já citada entrevista para o jornalista Bill Moyers, Joseph Campbell afirma que:

Os mitos servem, primariamente, para fornecer instruções fundamentais [...]. A sociedade atual não nos dá a instrução mítica adequada [...], e por isso os jovens têm dificuldades de encontrar o seu caminho. [...] É perfeitamente possível alguém ser influenciado pelos ideais e pela autoridade dos outros, a ponto de ignorar o que desejaria e poderia ser. Quem cresce num ambiente extremamente restritivo e autoritário dificilmente chegará a atingir o conhecimento de si mesmo.

[...] A história do filme tem a ver com uma operação de princípios [...]. As máscaras de monstros, usadas pelos atores de Guerra nas Estrelas, representam a verdadeira força

${ }^{76}$ Utilizamos aqui a seguinte edição: BÍBLIA DE JERUSALÉM. Tradução do texto em língua portuguesa diretamente dos originais. São Paulo: Sociedade Bíblica Católica Internacional / Paulus, 1995.

77 KIRK. A Arte Normativa e os Vícios Modernos. p. 1002-03. monstruosa, no mundo moderno. Quando a máscara de Darth Vader é retirada, você vê um rosto informe, de alguém que não se desenvolveu como indivíduo humano. $\mathrm{O}$ que se vê é uma espécie de fase indiferenciada, estranha e digna de pena.

[...] Darth Vader não desenvolveu a própria humanidade. É um robô. É um burocrata, vive não nos seus próprios termos, mas nos termos de um sistema imposto [...].

[...] O filme comunica. E concebido numa linguagem que fala aos jovens, e isso é o que conta. Ele pergunta: Você será uma pessoa de coração, verdadeiramente humana [...].

[...] Guerra nas Estrelas não é apenas uma história de moralidade, o filme tem a ver com os poderes da vida, conforme sejam plenamente realizados ou cerceados e suprimidos pela ação do homem ${ }^{78}$.

A questão das máscaras de monstros ressaltada por Joseph Campbell, em especial a máscara desumanizadora de Darth Vader, é uma imagem marcante que nos remete, mais uma vez, à análise literária de Northrop Frye, quando afirma que:

A característica essencial da máscara ideal é a exaltação do público, que forma o destino de sua progressão. No auto, o drama está em sua forma mais objetiva; o papel do público é aceitar a história sem julgamento. Na tragédia, há julgamento, mas a fonte esta no outro lado do palco; e, o que quer que seja ele; é mais forte que o público. Na peça irônica, o público e o drama confrontam-se diretamente; na comédia a fonte do reconhecimento chegou ao próprio público. A máscara ideal coloca o público em uma posição de superioridade quanto ao reconhecimento. A ação verbal de Fígaro é cômica e a de Don Giovanni, trágica; contudo, em ambos os casos, a plateia é exaltada pela música acima do alcance da tragédia e da comédia, e, apesar de tão profundamente tocada como sempre, não está emocionalmente envolvida com o reconhecimento do enredo ou das personagens. Ela contempla a queda de Don Juan como um entretenimento espetacular, de forma semelhante à que os

\footnotetext{
${ }^{78}$ CAMPBELL \& MOYERS. O Poder do Mito. p. 152-54.
} 
deuses supostamente contemplam a queda de Ájax ou Dario. A mesma sensação de ver a mimese dramática em meio a uma névoa de arrebatamento espetacular é também de importância central no cinema $[. . .]^{79}$.

O caráter simultâneo mimético e espetacular da narrativa da Space Opera de George Lucas, adornados tanto por elementos trágicos quanto cômicos, possibilitam ao expectador contemplar de uma posição privilegiada a queda e a redenção de Anakin Skywalker. No entanto, fora do ambiente do espetáculo, em nossa vida cotidiana, a máscara de Darth Vader pode atuar como um alerta para compreendermos a natureza de nosso livre-arbítrio, razão pela qual não devemos corromper esse caráter divino de nossa humanidade ao trocar a ordem interior e a liberdade individual pelas promessas mundanas de poder. A riqueza simbólica das jornadas heroicas percorridas pelas personagens dessa saga, em especial a tragédia de Anakin Skywalker / Darth Vader, ao abranger diferentes temas éticos, pode servir como um válido meio pedagógico para que as novas gerações entendam a importância de um correto entendimento da ordem, da liberdade e da justiça. Limitaremos, todavia, nossa análise aos aspectos centrais da Filosofia Moral e da Teoria Política subjacentes ao universo ficcional de Star Wars. cos

${ }^{79}$ FRYE. Anatomia da Crítica. p. 449. 